\title{
Influence of Farmer Capacity Building in Financial Resource Mobilization on Performance of Smallholder Irrigation Projects in Migori County, Kenya
}

\author{
L. O. Asawo ${ }^{1}$, A. Aseey ${ }^{1} \&$ J. R. Chandi ${ }^{1}$ \\ ${ }^{1}$ Faculty of Business and Management Sciences, University of Nairobi, Kenya \\ Correspondence: Leopold O. Asawo, Faculty of Business and Management Sciences, University of Nairobi, P.O. \\ Box 3035-40100, Kisumu, Kenya. Tel: 254-721-757-882. E-mail: asawoleo@gmail.com
}

Received: June 13, 2021

Accepted: September 23, 2021

Online Published: October 15, 2021

doi:10.5539/jas.v13n11p54

URL: https://doi.org/10.5539/jas.v13n11p54

\begin{abstract}
The study examined influence of farmer capacity building in financial resource mobilization on performance of smallholder irrigation projects in Migori County, Kenya. The study adopted pragmatism as its philosophy, and used cross sectional and correlation research design. The target population was 2,815 , and comprised farmers from fifteen smallholder irrigation projects that receive water from River Kuja through Lower Kuja Project. The sample size was 341 farmers. The study used systematic random sampling to draw the sample, used questionnaire to collect data, and analyzed data using descriptive and inferential statistics. The results showed that farmer capacity building in financial resource mobilization has a significant influence on performance of smallholder irrigation projects $\left(\mathrm{r}=801, \mathrm{R}^{2}=0.641, \mathrm{~F}(5,331)=118.405,0.000<\mathrm{p}<0.05\right)$. Therefore, the study concluded that financial resource mobilization is a critical factor in performance of smallholder irrigation projects in Migori County. Consequently, the study recommends that Migori County Government educate farmers in smallholder irrigation projects on loan facilities by financial institutions. Further, the study recommends that Migori County develop a framework to assist farmers in smallholder irrigation projects to qualify for loans facilities operated by financial institutions.
\end{abstract}

Keywords: financial resource mobilization, critical success factors, smallholder irrigation.

\section{Introduction}

Since early civilization, man has used irrigation to guarantee food production. Irrigation produces forty and seventeen percent, respectively, of food in the world and in developing nations (Asian Development Bank [ADB], 2015), and by 2027 irrigation could account for 80\% of the world's food needs (Vermillion, 1997 as cited in Kahuro, 2012). Siebert et al. (2005) stated that the largest irrigation areas are found along Rivers Indus and Ganges in Northern India and Pakistan, respectively; Yangtaz, Huang $\mathrm{He}$ and Hai He Basins in China; Mississippi-Missouri River Basin in California USA; and River Nile in Sudan and Egypt. Despite offering a strategy for addressing hunger and poverty in rural areas, irrigation has not translated into project success in Kenya. For instance, studies in Migori County identified irrigation potential in the county from Rivers Kuja and Migori as being in excess of 16,500 hectares (GIBB Africa, 2011). However, Kenya National Bureau of Statistics [KNBS] (2018) described food poverty in Migori County as 32\%, twice that in Nyeri and Meru Counties $(15.5 \%$ each), and stated that poverty incidence in Migori County was $41.2 \%$, higher than the national figure of $36.1 \%$. The inability by Migori County to exploit its irrigation potential could be a pointer to existence of a gap in knowledge on project management between researchers and practitioners. Projects management practitioners consider planning, project implementation, cost and time overruns and quality as main concerns in project management (Alias et al., 2014). However, Golini et al. (2017) argued that project success entails use of project-specific approaches to development, and Alias et al. (2014) advised that project based research on critical success factors (CSFs) is more beneficial to project performance.

Studies have attempted to identify causes of poor performance in smallholder irrigation projects. For example, Salami et al. (2010) attributed poor performance in smallholder irrigation in SSA to amongst other factors, lack of finances. Similarly, Dlamini et al. (2014), and Mutambara and Munodawafa (2014) described lack of finances as the cause of poor performance of irrigation by smallholder farmers in Swaziland and Zimbabwe, respectively. 
Simpson et al. (2003) stated that communities already over-stretched by daily financially needs are unable to contribute resources to project initiatives. Socio-economic factors influence the ability of farmers to utilize opportunities in smallholder irrigation (Omoregbee et al., 2013), and access to credit enables smallholder farmers to purchase farm inputs and to hire labor (Agwu \& Edun, 2007). However, while Montaña at al. (2009) stated that failure to consider socioeconomic characteristics of farmers leads to flaws in project conceptualization, planning and implementation, Food and Agricultural Organization [FAO] (2008) stated that despite enormous funds dedicated to agriculture, rural agriculture had continued to perform poorly, and added that there was little to show for the funds spent in smallholder agriculture. Thus, FAO advised on review of agricultural financing to include savings by farmers, crop insurance, money transfer and leasing. The study found that, whereas other researchers identify lack of finances as causing poor performance in smallholder irrigation projects, there is a gap in knowledge on how capacity building in financial resource mobilization influence performance of smallholder irrigation projects. Thus, the study viewed financial resource mobilization as a critical success factor in performance of smallholder irrigation projects in Migori County, Kenya. New knowledge on financial resource mobilization could inform development of financial facilities for smallholder irrigation projects.

The study tested the following hypothesis; "H1: Farmer capacity building in financial resource mobilization has a significant influence on performance of smallholder irrigation projects". In the study, financial resource mobilization is an independent variable and refers to personal savings and assets, agricultural cooperative society loans, commercial bank loans, non-governmental organizations loans, and governmental organizations loans. Performance of smallholder irrigation projects is the dependent variable, and refers to irrigation water supply, farm labor demand, household food production, farm income generation, and environmental and social mitigation. The study used Resource Based View (RBV) Theory to ground the research. RBV theory dates back to Penrose's view of organization as a pool of resources in 1950. RBV theory considers resources of a firm as a fundamental predictor of a firm's competitive advantage and performance. Whereas there are different ways of categorizing resources, tangible resources are those that facilitate execution of business process, while intangible resources are ones that might result in competitive advantage by allowing organizations to incorporate unique and valuable practices (Ruivo, Oliveira, \& Neto, 2015). As noted by Hitt, Carnes, and Xu (2016), RBV is based on two assumptions of resources; being heterogeneously distributed across organizations; and non-transferability of productive resources from one organization to another without incurring cost. Thus, RBV holds that only an intangible resource that is valuable, rare, hard to imitate and without strategically equivalent substitutes is critical in sustaining a firm's competitiveness (Ruivo, Oliveira, \& Neto, 2015). The theory is relevant to the study as it notes that there is need for adequate financial resources to ensure better performance of smallholder irrigation projects in Migori County, and hence the need to mobilize financial resource. However, critics of the theory argue that it is not possible to test RBV due to lack of a methodology to measure intangible resources (Kozlenkova, Samaha, \& Palmatier, 2014).

\section{Material and Methods}

\subsection{Research Philosophy and Design}

The study adopted pragmatism as its philosophy. The study used cross-sectional and correlational research design. Due to lack of funding, the study desired to use a method that would be cheap and cost effective. Thus, the study used cross-sectional research because of its advantage in enabling a one-time process of data collection from a population. Cross-sectional research is useful in describing a population and in determining prevalence of an outcome at a given time (Levin, 2006). Further, cross-sectional research is cheaper, compared to longitudinal design, and more appropriate for researchers working under budgetary constraints (Rindfleisch et al., 2008). Similarly, in order to understand the relationships between famer capacity building in financial resource mobilization and performance of smallholder irrigation projects, the study used correlational research. Correlational research is useful in determining relationships among variables and in forecasting events from existing information (Curtis et al., 2016).

\subsection{Target Population}

The target population comprised 2,815 farmers undertaking irrigation in fifteen smallholder irrigation projects in Migori County. The study selected the fifteen smallholder irrigation projects because National Irrigation Authority (NIA) has constructed the project to provide water from River Kuja for irrigation in Migori County, and the fifteen irrigation projects benefit from the project. The fifteen smallholder irrigation projects are members of the water user's association (Lower Kuja Irrigation Water Project [LOKIWAP]) and receive water through the Lower Kuja Project. The target population comprised farmers who are members of the fifteen irrigation projects in Migori County that receive water from River Kuja, as part of Lower Kuja Project. 


\subsection{Sample Size and Sampling Procedure}

The study purposely selected all the fifteen smallholder irrigation projects in Migori County that are members of the water user's association (Lower Kuja Irrigation Water Project [LOKIWAP]), and that receive water from River Kuja through the Lower Kuja Project. Further, the researcher used systematic random sampling procedure to select the sample from the sampling frame. According to Krejcie and Morgan (1970), sample size for a population of 2800 is 338 , while that for a population of 3000 is 341 . The target population $(\mathrm{N})$ was 2815 , which falls in between 2800 and 3000 . Hence, the study adopted the next highest value of 341 as its sample size (n). Using $\mathrm{N}=2,815$ and $\mathrm{n}=341$, the study sampling interval $(\mathrm{R})$ was eight.

\subsection{Data Collection Instruments}

The study considered the questionnaire as a quick and cost effective method of collecting data. Thus, the study used a questionnaire to collect data from farmers. The study assumed that all farmers are well versed in project activities, and would base their response on experiences and insight in smallholder irrigation projects in Migori County.

\subsubsection{Operationalization of Variables}

Table 1 presents operationalization of the study variables.

Table 1. Operationalization of the study variables

\begin{tabular}{|c|c|c|}
\hline Variable & Indicators & Measurement \\
\hline \multirow{5}{*}{$\begin{array}{l}\text { Independent Variable: } \\
\text { Financial resource } \\
\text { mobilization. }\end{array}$} & Personal savings and assets. & Number of farmers who use personal savings and assets to finance farming. \\
\hline & Agricultural cooperatives society loans. & Number of farmers who use agricultural cooperatives society loans to finance farming. \\
\hline & Commercial bank loans. & Number of farmers who use commercial bank loans to finance farming. \\
\hline & Non-governmental organization loans. & Number of farmers who use non-governmental organization loans to finance farming. \\
\hline & Governmental organization loans. & Number of farmers who use governmental organization loans to finance farming. \\
\hline \multirow{5}{*}{$\begin{array}{l}\text { Dependent Variable: } \\
\text { Performance of smallholder } \\
\text { irrigation projects. }\end{array}$} & Irrigation water supply. & Number of farmers who receive adequate irrigation water supply. \\
\hline & Farm labor requirements. & Number of farmers who employ labor during an irrigation season. \\
\hline & Household food production. & Number of farmers who meet household food needs from irrigation \\
\hline & Farm income generation. & Number of farmers who meet financial needs from irrigation. \\
\hline & Environmental and social mitigation. & Number of farmers who mitigate environmental and social concerns. \\
\hline
\end{tabular}

\subsubsection{Pilot Testing}

The study tested the questionnaire prior to use. Hilton (2015) described piloting as important in ensuring that respondents perceive and understand questions as intended by the researcher. The study tested the questionnaire in Lower Sio Project in Busia County, Kenya. This is because Lower Sio Project, also implemented under NIA, underwent similar development approach as Lower Kuja Project. Farmers in Lower Sio Project also share similar conditions to those in Lower Kuja Project, and would therefore most likely respond in the same manner. Lancaster et al. (2002) recommended use of 30 cases in a pilot study, while Mugenda and Mugenda (2003) recommended use of ten percent of the sample in a pilot study. The pilot study adopted 34 cases, translating to ten percent of the sample size, as recommended by Mugenda and Mugenda.

\subsubsection{Validity of Research Instruments}

Validity assesses how findings help to explain test scores of an investigation (Urbina, 2004). The study addressed content-related validity by peer review, criterion-related validity by correlating test scores with predicted criteria (predictive validity) and with existing criteria (concurrent validity), and construct validity by ensuring correlation of scores (convergence) and score differentiation based on variables (divergence).

\subsubsection{Reliability of Research Instruments}

Reliability concerns trustworthiness of scores provided by an instrument, and describes consistency of an instrument in providing consistent results over time (Caruth, 2013). Reliability also indicates the error in scores (Urbina, 2004). Urban described the Kuder-Richardson formula 20 (K-R 20) and Cronbach's alpha (coefficient alpha, $\alpha$ ) as two most commonly used methods to determine reliability of instruments in social science. The researcher used Cronbach's alpha (coefficient alpha, $\alpha$ ) given by Urbina (2004), shown below, to determine reliability. 


$$
\alpha=\frac{\mathrm{n}}{\mathrm{n}-1} \times \frac{\mathrm{S}_{\mathrm{t}}^{2}-\Sigma\left(\mathrm{S}_{\mathrm{i}}^{2}\right)}{\mathrm{S}_{\mathrm{t}}^{2}}
$$

Where, $\alpha=$ Cronbach's coefficient alpha; $\mathrm{n}=$ number of items in the test; $S_{t}^{2}=$ variance of total scores in the test; $\Sigma\left(S_{i}^{2}\right)=$ sum of the variance of item scores.

\subsection{Data Collection Procedures}

Before data collection, the researcher sought permission from the University of Nairobi (UON) and National Council for Science, Technology and Innovation (NACOSTI) to undertake the study. This is a requirement for undertaking research activities in Kenya. After securing the research permit, the researcher mobilized to site, and held introductory meetings with local county and national government officials in the project area, and farmers' leaders. Thereafter, the researcher recruited five research assistants to administer the questionnaire. The researcher trained the research assistants on ethics of social research to ensure that they understand how to administer the research instrument. Data collection took five days, comprising one day for mobilization and training of research assistants, three days for administering of the questionnaire, and one day for debriefing.

\subsection{Data Analysis Techniques}

The study used descriptive and inferential statistics to analyses the data. Descriptive statistics included central tendency (mean) and variability (standard deviation), while inferential statistics included Pearson's correlation analysis. The study tested the null hypothesis described below, and analyzed Pearson product moment correlation $(\mathrm{r})$ and stepwise regression $\left(\mathrm{r}^{2}\right)$ based on $\mathrm{p}<0.05$ and $95 \%$ confidence level.

In the study, capacity building refers to inputs into project management that aim to improve the ability of individual farmers or groups of farmers in the smallholder irrigation projects to "produce, perform or achieve" their tasks and objectives effectively and efficiently in line with the objectives of Lower Kuja Project. Commercial banks listed in the study were Kenya Commercial Bank, Equity Bank, Cooperative Bank and ABSA Non-governmental organizations listed in the study were CARE (K) and One Acre Fund, while governmental organizations listed in the study were Uwezo Fund, Women Development Fund, Youth Fund and Agricultural Finance Corporation.

Test for null hypothesis; H1: Farmer capacity building in financial resource mobilization has a significant influence on performance of smallholder irrigation projects.

The regression model took the form shown in Equation 2.

$$
\mathrm{Y}=\mathrm{a}+\mathrm{b}_{1} \mathrm{X}_{1}+\mathrm{b}_{2} \mathrm{X}_{2}+\mathrm{b}_{3} \mathrm{X}_{3}+\mathrm{b}_{4} \mathrm{X}_{4}+\mathrm{b}_{5} \mathrm{X}_{5}+\varepsilon
$$

Where, $\mathrm{Y}=$ performance of smallholder irrigation projects; $\mathrm{a}=\mathrm{Y}$ intercept; $\mathrm{b}_{1}, \mathrm{~b}_{2}, \mathrm{~b}_{3}, \mathrm{~b}_{4}, \mathrm{~b}_{5}=$ regression coefficients; $\mathrm{X}_{1}=$ Personal savings and assets; $\mathrm{X}_{2}=$ Agricultural cooperatives society loans; $\mathrm{X}_{3}=$ Commercial bank loans; $\mathrm{X}_{4}=$ Non-governmental organization loans; $\mathrm{X}_{5}=$ Governmental organization loans; $\varepsilon=$ error term.

\section{Results and Discussion}

This section presents findings and discussion under the study. The study conducted Analysis of variance (ANOVA) using least significant difference test at $\mathrm{p}=0.05$, and compared the means using SPSS computer package.

\subsection{Questionnaire Response Rate}

The study targeted 341 respondents. Table 2, response rate, shows that 337 returned fully filled questionnaires, translating to a response rate of $98.8 \%$. A response rate of $70 \%$ and above is significant for statistical analysis (Sheehan, 2001). The study concluded that the response rate of $98.8 \%$ was significant for statistical analysis. 
Table 2. Questionnaire response rate

\begin{tabular}{llll}
\hline Name of Irrigation Scheme & Sample & Response & Percentage \\
\hline Orango (Block M) & 3 & 3 & 100.0 \\
Owiro (Block 1.1) & 19 & 19 & 100.0 \\
Bala (Block 1.2) & 5 & 5 & 100.0 \\
Aego (Block 2.1) & 17 & 16 & 94.1 \\
East Kanyuor (Block 2.2) & 37 & 37 & 100.0 \\
Akala (Block 2.3) & 27 & 27 & 100.0 \\
Sagama (Block 3) & 33 & 33 & 100.0 \\
Obware (Block 4.1) & 25 & 25 & 100.0 \\
Magunga (Block 4.2) & 40 & 39 & 97.5 \\
Oguta (Block 4.3) & 13 & 13 & 100.0 \\
Angugo (Block 5.1) & 21 & 21 & 100.0 \\
Kaka (Block 5.2) & 16 & 16 & 100.0 \\
Kabuto (Block 6) & 29 & 28 & 96.6 \\
Kimai (Block 7) & 22 & 22 & 100.0 \\
Kanyarwanda (Block 8) & 34 & 33 & 97.1 \\
Overall response rate & 341 & 337 & 98.8 \\
\hline
\end{tabular}

\subsection{Descriptive Statistics}

The study asked respondents to indicate their level of agreement with various statements on financial resource mobilization (personal savings and assets, agricultural cooperatives society loans, commercial bank loans, non-governmental organization loans, and governmental organization loans).

Using SPSS computer package, the study determined the means and standard deviation based on the responses given by respondents on the various statement on financial resource mobilization. Tables 3-7 present means and standard deviation on responses given by respondents.

Table 3. Agreement with statements on personal savings and assets

\begin{tabular}{lll}
\hline & Mean & Std. Dev. \\
\hline I do not know of any organization that gives loans to farmers. & 2.395 & 1.033 \\
I have never received a loan from any organization for farming. & 2.872 & 1.241 \\
I have never applied for a loan from any organization for farming. & 2.932 & 1.288 \\
I only use my personal savings and assets for farming. & 3.086 & 1.341 \\
I prefer to use my personal savings and assets for farming. & 3.427 & 1.160 \\
\hline
\end{tabular}

Table 4. Agreement with statements on agricultural cooperatives society loans

\begin{tabular}{lll}
\hline & Mean & Std. Dev. \\
\hline I am a member of a cooperative society that gives loans to farmers. & 1.825 & 0.674 \\
I use loans from the cooperative society for farming. & 1.792 & 0.630 \\
Loan conditions by cooperative societies are easy to meet. & 2.469 & 0.694 \\
I repay loans from the cooperative society from sale of farm produce. & 1.878 & 0.655 \\
I prefer to use cooperative society loans for farming. & 3.175 & 1.186 \\
\hline
\end{tabular}

Table 5. Agreement with statements on commercial bank loans

\begin{tabular}{lll}
\hline & Mean & Std. Dev. \\
\hline I have an account with a commercial bank that gives loans to farmers. & 1.825 & 0.674 \\
I use loans from the commercial bank for farming. & 1.792 & 0.630 \\
Loan conditions by commercial banks are easy to meet. & 2.469 & 0.694 \\
I repay loans from the commercial bank from sale of farm produce. & 1.864 & 0.597 \\
I prefer to use commercial bank loans for farming. & 2.988 & 1.261 \\
\hline
\end{tabular}


Table 6. Agreement with statements on non-governmental organizations loans

\begin{tabular}{lll}
\hline & Mean & Std. Dev. \\
\hline I am a member of a non-governmental organization that gives loans to farmers. & 1.994 & 0.852 \\
I use loans from a non-governmental organization for farming. & 1.991 & 0.836 \\
Loan conditions by non-governmental organizations are easy to meet. & 2.573 & 0.806 \\
I repay loans from the non-governmental organization from sale of farm produce. & 2.062 & 0.899 \\
I prefer to use non-governmental organization loans for farming. & 3.427 & 1.183 \\
\hline
\end{tabular}

Table 7. Agreement with statements on governmental organizations loans

\begin{tabular}{lll}
\hline & Mean & Std. Dev. \\
\hline I am a member of a governmental organization that gives loans to farmers. & 1.727 & 0.531 \\
I use loans from the governmental organization for farming. & 1.766 & 0.513 \\
Loan conditions by governmental organizations are easy to meet. & 2.380 & 0.639 \\
I repay loans from the governmental organization from sale of farm produce & 1.816 & 0.465 \\
I prefer to use governmental organization loans for farming. & 3.279 & 1.217 \\
\hline
\end{tabular}

The results in Table 3 show that whereby farmers are aware that there are organizations from where they could acquire loans for farming; farmers depend on their personal savings and assets for farming. Machethe et al. (2004) and Dlamini et al. (2014) identified lack of credit as a major contributor to poor performance in the smallholder irrigation sector. Further, from the findings in Table 3, farmers were non-committal on whether they preferred to use their personal savings and assets for farming, whether they had applied for a loan from any organization for farming, and whether they had received a loan from any organization for farming. The results suggest that farmers do not have a strategy to acquire financial resources for farming. Not surprising then, Omoregbee et al. (2013) stated that socio-economic factors influence the ability of farmers to use the opportunities in smallholder irrigation projects.

As per the findings in Table 4, respondents were non-committal on whether or not they preferred to use loan facilities from cooperative societies for farming. However, despite reporting that they were not members of cooperative societies that gives loans to farmers, respondents felt that loans conditions by cooperative societies were not easy to meet. This finding raises a question on why farmers would think that loan conditions by cooperative societies are difficult to meet, yet they are not members of any cooperative society. The finding suggests that there is misconception within the project area on the operations of cooperative societies. No wonder then, the respondents reported that they had not used loan facilities from cooperative societies to undertake farming. Likewise, the respondents reported that they had not used proceeds from the sale of farm produce to repay loans from cooperative societies. Ashraf et al. (2009) stated that poor farm practices and poor quality control inhibits commercialization of agriculture by smallholder farmers. Cooperative societies offer more to farmers than loan facilities.

According to the findings in Table 5, respondents were non-committal on whether or not they preferred to use loan facilities from commercial banks for farming. However, despite reporting that they did not have an account with a commercial bank that gives loans to farmers, respondents felt that loans conditions by commercial banks were not easy to meet. This finding raises a question on why farmers would think that loan conditions by commercial banks are difficult to meet, yet they did not have an account with a commercial bank that gives loans to farmers. The finding suggests that there is misconception within the project area on the operations of commercial banks. No surprising then, the respondents reported that they had not used loan facilities from commercial banks to undertake farming. Likewise, the respondents. Mutambara and Munodawafa (2014) reported that smallholder farmers in Zimbabwe lacked access to bank loans and that only 40 to $67 \%$ had access to fertilizers and pesticides, while only $17 \%$ had access to farm input loans.

Table 6 shows that respondents were non-committal on whether or not they preferred to use loan facilities from non-governmental organizations for farming. Likewise, respondents were non-committal on whether or not loan conditions by non-governmental organizations were easy to meet. Assuming that non-committal response represented a more favorable opinion than outward rejections, the finding would suggest that farmers have a more favorable opinion on loan facilities by non-governmental organizations compared to cooperative societies, commercial banks or government-based organizations. This means that non-governmental organizations are more likely to receive a more positive response or loans update in the project area compared to other 
organizations. GIBB Africa (2011) advised the NIA to enlist non-governmental organizations with experience in community financing to provide credit facilities to farmers in Lower Kuja Project.

From Table 7, the results show that respondents were non-committal on whether or not they preferred to use loan facilities from governmental agency loans for farming. However, despite reporting that they were not members of any governmental organization that gives loans to farmers, respondents felt that loans conditions by governmental organizations were not easy to meet. This finding raises a question on why farmers would think that loan conditions by governmental organizations are difficult to meet, yet they are not members of any governmental organization. The finding suggests that there is misconception within the project area on the operations of governmental organizations. In addition, the respondents reported that they had not used loan facilities from governmental organizations to undertake farming, and that they had not used proceeds from the sale of farm produce to repay loans from governmental organizations.

\subsection{Inferential Statistics}

The study used regression analysis to test the hypothesis: "H1: Farmer capacity building in financial resource mobilization has a significant influence on performance of smallholder irrigation projects". Tables 8-10 present data analyses and results of regression analysis for influence of farmer capacity building in financial resource mobilization on performance of smallholder irrigation projects.

Table 8. Model summary

\begin{tabular}{lllll}
\hline Model & $\mathrm{R}$ & R Square & Adjusted R Square & Std. Error \\
\hline 1 & $.801^{\mathrm{a}}$ & .641 & .636 & .319 \\
\hline
\end{tabular}

Note. ${ }^{\text {a }}$ Predictors: (Constant), Personal savings and assets, Agricultural cooperatives society loans, Commercial bank loans, Non-governmental agency loans, Governmental agency loans.

Table 9. Analysis of Variance (ANOVA)

\begin{tabular}{|c|c|c|c|c|c|c|}
\hline \multicolumn{2}{|c|}{ Model } & Sum of Squares & $\mathrm{df}$ & Mean Square & $\mathrm{F}$ & Sig. \\
\hline 1 & Regression & 61.041 & 5 & 12.208 & 118.405 & $.000^{\mathrm{b}}$ \\
\hline & Residual & 34.128 & 331 & 0.103 & & \\
\hline & Total & 95.169 & 336 & & & \\
\hline
\end{tabular}

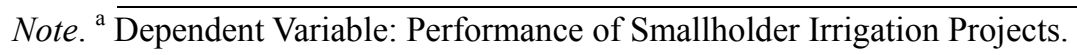

${ }^{\mathrm{b}}$ Predictors: (Constant), Personal savings and assets, Agricultural cooperatives society loans, Commercial bank loans, Non-governmental agency loans, Governmental agency loans.

Table 10. Regression coefficients

\begin{tabular}{|c|c|c|c|c|c|c|}
\hline \multirow{2}{*}{\multicolumn{2}{|c|}{ Model }} & \multicolumn{2}{|c|}{ Unstandardized Coefficients } & \multirow{3}{*}{$\begin{array}{l}\text { Standardized Coefficients } \\
\text { Beta }\end{array}$} & \multirow{3}{*}{$\begin{array}{l}\mathrm{T} \\
10.598\end{array}$} & \multirow{3}{*}{$\begin{array}{l}\text { Sig. } \\
.000\end{array}$} \\
\hline & & \multirow{2}{*}{$\begin{array}{l}\mathrm{B} \\
1.081\end{array}$} & \multirow{2}{*}{$\begin{array}{l}\text { Std. Error } \\
0.102\end{array}$} & & & \\
\hline 1 & (Constant) & & & & & \\
\hline & Personal savings and assets & 0.678 & 0.143 & 0.772 & 4.741 & .000 \\
\hline & Agricultural cooperatives society loans & 0.816 & 0.105 & 0.851 & 7.771 & .000 \\
\hline & Commercial bank loans & 0.611 & 0.147 & 0.678 & 4.156 & .000 \\
\hline & Non-governmental agency loans & 0.719 & 0.144 & 0.814 & 4.993 & .000 \\
\hline & Governmental agency loans & 0.602 & 0.145 & 0.673 & 4.152 & .000 \\
\hline
\end{tabular}

Note. ${ }^{\text {a }}$ Dependent Variable: Performance of Smallholder Irrigation Projects.

From the findings in Table $8, \mathrm{r}=0.801$. This indicates that farmer capacity building in financial resource mobilization (personal savings and assets, agricultural cooperatives society loans, commercial bank loans, non-governmental organization loans and governmental organization loans) has a strong relationship with performance of smallholder irrigation projects in Migori County. From Table $8, \mathrm{R}^{2}=0.641$, indicating that farmer capacity building in financial resource mobilization (personal savings and assets, agricultural cooperatives society loans, commercial bank loans, non-governmental organization loans and governmental 
organization loans) explains $64.1 \%$ of variations in performance of smallholder irrigation projects in Migori County.

According to Table 9, ANOVA table, the regression model shows that p-value is 0.000 and F-calculated is 118.405. Since, p-value is less than 0.05 and F-calculated is greater than F-critical (2.2413), then the regression model was significant in determining how personal savings and assets, agricultural cooperatives society loans, commercial bank loans, non-governmental organization loans and governmental organization loans influence performance of smallholder irrigation projects in Migori County, Kenya.

Table 10 presents the following results: personal savings and assets $(\beta=0.678, p=0.000)$, agricultural cooperatives society loans $(\beta=0.816, \mathrm{p}=0.000)$, commercial bank loans $(\beta=0.611, \mathrm{p}=0.000)$, non-governmental organization loans $(\beta=0.719, p=0.000)$ and governmental organization loans $(\beta=0.602, p=$ 0.000 ). Hence, test of significance shows that personal savings and assets, agricultural cooperatives society loans, commercial bank loans, non-governmental organization loans and governmental organization loans are significant at $p<0.05$ and $95 \%$ confidence level. This implies that farmer capacity building in financial resource mobilization has a significant influence on performance of smallholder irrigation projects in Migori County, Kenya. Therefore, the alternate hypothesis was accepted and a conclusion made that farmer capacity building in financial resource mobilization has a significant influence on performance of smallholder irrigation projects in Migori County, Kenya. Lack of financial resource inhibits commercialization of agriculture by smallholder farmers in Swaziland and Zimbabwe (Mutambara \& Munodawafa, 2014). FAO (2008) advised on the need to review agricultural financing to include savings, crop insurance, money transfers and leasing.

\section{Conclusion and Recommendations}

The study concluded that while farmers in smallholder irrigation projects in Migori County are aware of financial institutions that offer financial loan facilities, farmers had a more favorable opinion on financial loan facilities by non-governmental organizations, but were hesitant to engage with cooperative societies, commercial banks or government based organizations. This was strengthen by the fact that farmers were not members of any cooperative society, nor did farmers have an account with any commercial bank or governmental organization, thus making it difficult for farmers to qualify for loan facilities by the financial institutions. Therefore, the study recommends that Migori County Government develop a framework to educate farmers in the smallholder irrigation projects in Migori County on benefits and demerits of using personal savings and assets, agricultural cooperatives society loans, commercial bank loans, non-governmental organization loans and governmental organization loans. Further, the study recommends that the county government develop a framework to assist smallholder irrigation projects in Lower Kuja Project to qualify for financial resource through loan facilities provided by agricultural cooperatives societies, commercial banks, non-governmental organizations and governmental organizations. In addition, the study recommends that NIA should enlist services of organizations that have experience in community financing to provide financial loan facilities to farmers in the smallholder irrigation projects in Migori County.

\section{References}

Agwu, A. E., \& Edun, O. A. (2007). Influence of farmers' demographic characteristics on knowledge gap of recommended fadama technologies in Ilaro Agricultural Zone of Ogun State. Journal of Agriculture, Food, Environment and Extension, 6(2), 52-59. https://doi.org/10.4314/as.v6i2.1571

Alias Z., Zawawi, E. M. A., Yusof, K., \& Aris, N. M. (2014). Determining critical success factors of project management practice: A conceptual framework. Procedia-Social and Behavioral Sciences, 153, 61-69. https://doi.org/10.1016/j.sbspro.2014.10.041

Asian Development Bank. (2015). Guidance note: Irrigation subsector risk assessment. Asian Development Bank, Manila, Philippines. Retrieved from https://www.adb.org/documents/guidance-note-irrigation-sub sector-risk-assessment

Curtis, E. A., Comiskey, C., \& Dempsey, O. (2016). Importance and use of correlational research. Nurse Researcher, 23(6), 20-25. https://doi.org/10.7748/nr.2016.e1382

Dlamini, N. S., Rowshon, M. K., Makhanya, M., \& Sithole, S. (2014). The CDAA Framework for Development of Sustainable Large-Scale Smallholder Irrigation Schemes in Swaziland. Agriculture and Agricultural Science Procedia, 2, 386-393. https://doi.org/10.1016/j.aaspro.2014.11.054

FAO (Food and Agricultural Organisation). (2008). Risk mitigation and management for agricultural investment: Investment and resource mobilization. Rome, Italy. Retrieved from https://www.farm-d.org/app/uploads/ 2019/05/Risk-Mit-and-Man-for-AgInvest.pdf 
GIBB Africa. (2011). Consultancy services for feasibility study, detailed design and preparation of tender documents for Lower Kuja Irrigation Development Project: Detailed designs (Unpublished technical report, GIBB Africa Limited, Nairobi, Kenya).

Golini, R., Corti, B., \& Landoni, P. (2017). More efficient project execution and evaluation with logical framework and project cycle management: Evidence from international development projects. Impact Assessment and Project Appraisal, 35(2), 128-138. https://doi.org/10.1080/14615517.2016.1239495

Hilton, C. E. (2015). The importance of pretesting questionnaires: A field research example of cognitive pretesting the exercise referral quality of life scale. International Journal of Social Research Methodology, 20(1). 21-34. https://doi.org/10.1080/13645579.2015.1091640

Hitt, M. A., Carnes, C. M., \& Xu, K. (2016). A current view of resource based theory in operations management: A response to Bromiley and Rau. Journal of Operations Management, 41(10), 107-109. https://doi.org/ 10.1016/j.jom.2015.11.004

Kahuro, G. W. (2012). Factors influencing farmers' participation in operation and maintenance of smallholder irrigation projects in Gichugu Division, Kirinyaga East District, Kenya (Master's Thesis, University of Nairobi, Nairobi, Kenya).

Kozlenkova, I. V., Samaha, S. A., \& Palmatier, R. W. (2014). Resource-based theory in marketing. Journal of the Academy of Marketing Science, 42(1), 1-21. https://doi.org/10.1007/s11747-013-0336-7

Krejcie, R. V., \& Morgan, D. W. (1970). Determining Sample Size for Research Activities. Educational and Psychological Measurement, 30, 607-610. https://doi.org/10.1177/001316447003000308

Lancaster, G. A., Dodd, S., \& Williamson, P. R. (2002). Design \& analysis of pilot studies: Recommendations for good practice. Journal of Evaluation in Clinical Practice, 10(2), 307-312. https://doi.org/10.1111/ j..2002.384.doc.X

Levin, K. A. (2006). Study design III: Cross-sectional studies. Evidence-Based Dentistry, 7(1), $24-5$. https://doi.org/10.1038/sj.ebd.6400375

Machethe, C. L., Mollel, N. M., Ayisi, K., Mashatola, M. B., Anim, F. D. K., \& Vanasche, F. (2004). Smallholder irrigation and agricultural development in the Olifants River Basin of Limpopo Province: Management transfer, productivity, profitability and food security issues. University of the North, School of Agriculture and Environmental Sciences, Limpopo, South Africa.

Montaña, E., Pastor, G., \& Torres, L. (2009). Socioeconomic issues in irrigation literature: Approaches, concepts, and meanings. Chilean Journal of Agricultural Research, 69(Suppl. 1), 55-67. https://dx.doi.org/10.4067/ S0718-58392009000500006

Mutambara, S., \& Munodawafa, A. (2014). Production challenges and sustainability of smallholder irrigation schemes in Zimbabwe. Journal of Biology, Agriculture and Healthcare, 4(15), 87-96.

Omoregbee, F. E., Ighoro, A., \& Ejembi, S. A. (2013). Analysis of the effects of farmers' characteristics on poverty status in Delta State. International Journal of Humanities and Social Science Invention, 2(5), 11-16. https://doi.org/10.9790/0837-0911118

Rindfleisch, A., Malter, A. J., Ganesan, S., \& Moorman, C. (2008). Cross-sectional verses longitudinal survey research. Journal of Marketing Research, 45(3), 1-23. https://doi.org/10.1509/jmkr.45.3.261

Ruivo, P., Oliveira, T., \& Neto, M. (2015). Using resource-based view theory to assess the value of ERP commercial-packages in SMEs. Computers in Industry, 73, 105-116. https://doi.org/10.1016/j.compind. 2015.06.001

Salami, A., Kamara, A. B., \& Brixiova, Z. (2010). Smallholder agriculture in East Africa: Trends, constraints and opportunities (Working Papers Series No. 105). African Development Bank, Tunis, Tunisia. Retrieved from https://commdev.org/pdf/publications/Smallholder-Agriculture-East-Africa-Trends-Constraints-Opport unities.pdf

Sheehan, K. B. (2003). E-mail survey response rates: A review. Journal of Computer-Mediated Communication, 6(2), JCMC621. https://doi.org/10.1111/j.1083-6101.2001.tb00117.x

Siebert, S., Döll, P., Hoogeveen, J., Faures, J. M., Frenken, K., \& Feick, S. (2005). Development and validation of the global map of irrigation areas. Hydrology and Earth System Sciences, 9, 535-547. https://doi.org/ 10.5194/hess-9-535-2005 
Simpson, L., Wood, L., \& Daws, L. (2003). Community capacity building: Starting with people not projects. Community Development Journal, 38(4), 277-286. https://doi.org/10.1093/cdj/38.4.277

\section{Copyrights}

Copyright for this article is retained by the author(s), with first publication rights granted to the journal.

This is an open-access article distributed under the terms and conditions of the Creative Commons Attribution license (http://creativecommons.org/licenses/by/4.0/). 